
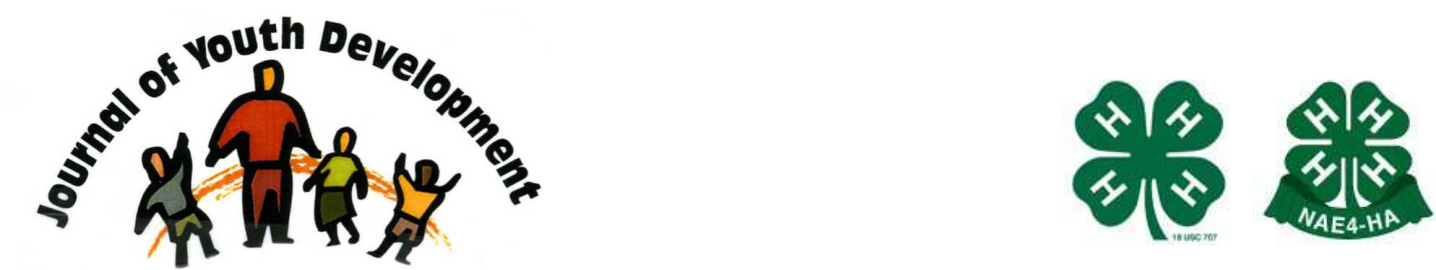

Bridging Research \& Practice

\title{
Cultures Around the World: A Unique Approach to Youth Cultural Diversity Education
}

\author{
Justen 0. Smith \\ Youth Development and 4-H \\ Utah State University \\ Farmington, Utah \\ justens@ext.usu.edu \\ Robert N. Pate \\ Youth Development and 4-H \\ Utah State University \\ Ogden, Utah \\ rpate@ext.usu.edu
}




\title{
JOURNAL OF YOUTH DEVELOPMENT \\ bridging research and practice

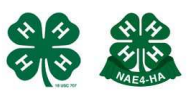

Article 0702PA003

\section{Cultures Around the World: \\ A Unique Approach to Youth Cultural Diversity Education}

\author{
Justen O. Smith and Robert N. Pate \\ Utah State University
}

\begin{abstract}
Increasingly diverse cultural trends have significant implications for the educational needs of American youth. Learning about and valuing diverse cultures will help prepare youth to become better citizens in an ever-changing society. Cultures Around the World was developed to meet the educational needs of youth in the area of cultural diversity. The Cultures Around the World program brings to life exciting cultures and customs from countries all over the world. Countries are presented in a unique format by teaching youth (ages 10 to 18 ) a specific country's history, culture, food, music, dance, language, religion, and current issues. The Cultures Around the World program can be used by any youth educator. The program comes in a ready to use $\mathrm{CD}$ containing presentations, handicraft instructions, language guides, and resource guides for nine different countries (Armenia, Australia, Ecuador, Egypt, England, France, Ghana, Slovakia and Mexico).
\end{abstract}

\section{Introduction}

The United States is becoming an increasingly diverse society. Today's neighborhoods and communities contain a complex mix of cultures, races, religions, and languages. From the year 2000 to 2050, it is projected that the U.S. population will experience a $71.3 \%$ increase of citizens of African descent, $212.9 \%$ increase of citizens of Asian descent, $187.9 \%$ increase of citizens of Hispanic origin, and a $217.1 \%$ increase of all other races (U.S. Census Bureau, 2004).

Today's cultural trends have significant implications for the educational needs of American youth (Ingram, 1999). Understanding, accepting, and valuing diverse cultures will help prepare youth to thrive in an ever-changing society (Gamino, \& Sneed, 1992). Helping youth develop cultural competence and teaching them to use time constructively are two key development 
assets identified for positive youth development identified by the Search Institute (Benson, 1997).

The authors have the primary responsibility of educating youth along the Wasatch Front of Northern Utah in a variety of methods. These methods include: school enrichment programs, afterschool programs, 4-H programs, and other in-formal educational programs. In working with youth along the Wasatch Front, the authors perceived a need for cultural and global education. Specific perceptions were that many youth cannot find countries on a map, do not follow current global issues, and in general lack an understanding of other cultures.

Both authors have worked and lived extensively overseas and realized a great opportunity to utilize their international experience in implementing a cultural education program for youth. There are many resources for cultural education. However, in the authors' searches there were no resources that encompassed an overall cultural education for youth. To create an overall package, Cultures Around the World was developed for youth ages 10-18.

\section{Program Objectives}

In planning the Cultures Around the World, the following program objectives were developed:

1. Youth will become more sensitive of the customs and background of the ethnic groups and immigrants living amongst them.

2. Youth will find joy in learning about other cultures and will pursue additional cultural education and travel to other countries, which in turn will make them better global citizens.

3. Youth will become acquainted with current global issues.

4. Youth will strive to educate others on cultural diversity and understanding.

5. Youth will have a better understanding of languages spoken in other countries.

6. Youth will learn where countries are located on a map.

\section{Teaching Methods}

To begin the Cultures Around the World program, Power Point ${ }^{\circledR}$ presentations were created for Armenia, Australia, Ecuador, France and Ghana. Each Power Point ${ }^{\circledR}$ presentation contains in depth information on each country including language guides, resource guides, handicraft instructions for younger youth and research project activities for older youth. Youth and youth educators participated in classes where each of these countries was presented. For each country, the subjects of history, language, traditional music and dance, food, religion, current issues, unique cultural traditions, current issues and geography were taught. To provide an even better understanding of each country, youth made a handicraft from the country being studied, tasted foods unique to the regions taught, and guest speakers native to the countries being presented were invited. Music CD's and cultural folk dance videos were also used. For each country presented, there was one hour of lecture and 30 minutes of tasting food and making a handicraft. Each class was capped at 25 students so each student would have a better learning environment. From November, 2004 to December, 2006 over 74 youth and youth educators had participated in the Cultures Around the World classes.

\section{Program Evaluation}

To determine program impact, evaluations were given to 74 youth and adult participants. 
The evaluation contained ten questions with each question answered on a scale from 1 to 4 with 1 (strongly disagree), 2 (somewhat disagree), 3 (agree), and 4 (strongly agree).

The last question of the evaluation, asks the participants the overall rating of the program again on a scale from 1 to 4 with 1 (poor), and 4 (excellent). The results of the evaluation along with the evaluation questions are listed in Table 1 . None of the participants marked strongly disagree on any of the evaluations. For this reason a column for strongly disagree was not included in the table.

Table 1

Results of the evaluation given to Cultures Around the World participants $(n=74)$

\begin{tabular}{|c|c|c|c|c|c|c|}
\hline \multirow[t]{2}{*}{ Evaluation Questions } & \multicolumn{2}{|c|}{$\begin{array}{c}\text { Somewhat } \\
\text { disagree }\end{array}$} & \multicolumn{2}{|c|}{ Agree } & \multicolumn{2}{|c|}{$\begin{array}{l}\text { Strongly agree } \\
\text { *(for question } \\
10 \text { Excellent) }\end{array}$} \\
\hline & Number & $\%$ & Number & $\%$ & Number & $\%$ \\
\hline $\begin{array}{l}\text { 1. This program provided me with a } \\
\text { better understanding of other cultures }\end{array}$ & & & 16 & 22 & 58 & 78 \\
\hline $\begin{array}{l}\text { 2. I will be more sensitive to other } \\
\text { ethnic groups living around me } \\
\text { because of this program }\end{array}$ & 4 & 5 & 18 & 24 & 52 & 71 \\
\hline $\begin{array}{l}\text { 3. Cultures Around the World helped } \\
\text { me to find countries on a map }\end{array}$ & 4 & 5 & 14 & 19 & 56 & 76 \\
\hline $\begin{array}{l}\text { 4. Cultures Around the World provided } \\
\text { a better understanding of languages } \\
\text { spoken in the countries studied }\end{array}$ & 1 & 7 & 19 & 26 & 49 & 67 \\
\hline $\begin{array}{l}\text { 5. The handicrafts made in Cultures } \\
\text { Around the World were educational as } \\
\text { well as fun }\end{array}$ & 1 & 2 & 4 & 5 & 69 & 93 \\
\hline $\begin{array}{l}\text { 6. I would recommend enrolling in } \\
\text { Cultures Around the World to my } \\
\text { friends }\end{array}$ & 1 & 1 & 10 & 14 & 63 & 85 \\
\hline $\begin{array}{l}\text { 7. If offered again with new countries } \\
\text { presented, I would enroll in the } \\
\text { program }\end{array}$ & 1 & 1 & 8 & 11 & 65 & 88 \\
\hline $\begin{array}{l}\text { 8. Cultures Around the World was an } \\
\text { interesting and exciting program }\end{array}$ & 2 & 3 & 9 & 12 & 63 & 85 \\
\hline $\begin{array}{l}\text { 9. Cultures Around the World has } \\
\text { provided me with an interest to further } \\
\text { study other countries, cultures, and } \\
\text { ethnic groups }\end{array}$ & & & 24 & 32 & 50 & 68 \\
\hline $\begin{array}{l}\text { 10. On a scale of } 1 \text { to } 4 \text { with } 1 \text { being } \\
\text { Very Poor and } 4 \text { being Excellent what } \\
\text { overall rating would you give Cultures } \\
\text { Around the World }\end{array}$ & & & 8 & 11 & 66 & 89 \\
\hline
\end{tabular}




\section{Program Results}

The Cultures Around the World program has consistently been a successful and educational program for youth and youth educators. In addition to teaching the Cultures Around the World classes locally, workshops have been conducted at two national conferences and one regional conference with an overall attendance of 110 youth educators. As a result of the positive response received from class participants, I developed curriculum in a user friendly CD format containing presentations, handicraft instructions, language guides, and resource guides that were peer reviewed and published for four different countries (Armenia, Australia, Ecuador, and France). The development and production of five more CD's for the countries (Egypt, England, Ghana, Mexico, and Slovakia) are currently in progress and are scheduled for completion in 2007. The format of each CD is outlined so that even if the educator has not traveled to these countries, they can still easily present the countries in a fun and exciting way. Along the Wasatch Front in Utah, the program has been expanded and offered during the weekly 4-H program at the Youth Center on Hill Air Force Base and the Syracuse afterschool program. Furthermore, the Davis School District has requested a Cultures Around the World teacher training workshop be offered to all social studies, geography, and language teachers in the district to help implement the program as a classroom resource. The Davis School District is the third largest school district in Utah (Utah Data Guide, 2003).

Surveys from program participants show the on-going success of the program. The Cultures Around the World program objectives are being met as shown by evaluation results listed in Table 1. Of particular importance are the results showing 24 percent agree and 71 percent strongly agree that they will be more sensitive to other ethnic groups living around them because of the program. Another significant result is that 32 percent agree and 68 percent strongly agree that Cultures Around the World has provided them with an interest to further study other countries, cultures, and ethnic groups.

\section{Conclusion and Discussion}

As a result of media publicity, training workshops, and classes, educators such as university faculty, school teachers, 4- $\mathrm{H}$ leaders, and scout leaders have requested the Cultures Around the World curriculum and $\mathrm{CD}$ sets. The enticing part of the program is that the educator implementing the program does not have to be an expert on the countries presented. The educator only needs to follow the instructions and use the resources that come with the CD of the country being studied.

The program can be implemented in classrooms, afterschool programs, school enrichment programs, 4-H programs, and any other youth program where cultural diversity is taught.

\section{References}

Benson, P.L. (1997). All kids are our kids: What communities must do to raise caring and responsible children and adolescents. San Francisco: Jossey-Bass.

Gamino, M., \& Sneed, J. (1992). Cross-cultural training practices and needs in the hotel industry. Hospitality Research Journal. 15(13), 13-26. 
Ingram, Patreese D. (1999). Attitudes of Extension professionals toward diversity education in 4-H programs. Journal of Extension. Volume 37, Number 1.

U.S. Census Bureau. (2004). U.S. interim projections by age, sex, race, and Hispanic origin. http://www.census.gov/ipc/www/usinterimproj/ Internet Release Date: March 18, 2004.

Utah Data Guide. (2003). Economic and Demographic Characteristics of Utah's School Districts. http://governor.utah.gov/dea/DataGuide/03SchoolDist04.pdf Internet Release Date: Spring 2003.

(C) Copyright of Journal of Youth Development Bridging Research and Practice. Content may not be copied or emailed to multiple sites or posted to a listserv without copyright holder's express written permission. Contact Editor at: patricia.dawson@oregonstate.edu for details. However, users may print, download or email articles for individual use.

ISSN 2325-4009 (Print); ISSN 2325-4017 (Online) 